\title{
The balance of change and continuity in the German construction sector's development path
}

\begin{abstract}
Major deficits, known as innovation gap or renewal paradox, related to the project-based production structures in construction, result in high knowledge waste and efficiency loss. Current innovation dynamics aim at overcoming these structural disadvantages by designing products and services set apart from the one-off project logic. They are heavily influenced by cross-sectoral knowledge combinations coming from the automotive industry, the service sector, engineering or information and communication technology (ICT), as well as by knowledge combinations which stem from integrating different trades into the planning process of a construction project. This paper argues that different kinds of knowledge combinations initiate various degrees of change within the existing sectoral structures. They indicate the sector's path plasticity.
\end{abstract}

Keywords: path plasticity, knowledge combinations, project-based industries, sectoral change, construction, innovation

\section{Introduction}

With its high share of physical work and usage of machinery equipment, the construction sector does not belong to the classic knowledgeintensive high-tech industries. Nevertheless, there is a high frequency of knowledge creation and application. Every construction project is adjusted to local circumstances and therefore has a large share of newly developed non-standardized components. With regard to planning, particular effort is put into combining the specifics of the local area with technical requirements, design aspects and regulatory, as well as environmental, standards. In the physical construction phase, new knowledge is created to solve unforeseen problems arising during the building process (Senaratne/SEXTon 2011). Such a situation brings together actors from different trades: engineers, architects or building owners and stimulates knowledge sharing and combinations which result in the development of new processes, communication structures, products or services.

However, a specific renewal paradox formulated two decades ago (KADEFORS 1995; EKSTEDT et al. 1992) is still existent in the construction sector: The project-based nature alongside a variety of actor constellations, theoretically, favours novelty, change and the freedom to experiment with new ideas. One might expect a high degree of flexibility as every project starts from scratch thereby requiring distinctive knowledge combinations and actions that continually reshape routinized behaviour and institutional settings. However, when new ideas and innovations are to be scaled-up, the project-based nature constitutes a major barrier since it hinders knowledge diffusion. The reasons are manifold but all originate from local circumstances of "projectification". Knowledge can be inappropriate for the next project, e.g. it does not match the requirements of the new locality, a particular actor constellation or machinery equipment as prerequisite for a specific application is not present, or knowledge has been forgotten (GRABHER 2004) due to non-existent (STYHRE 2008) or not consulted (LARSEN 2011) company-internal project evaluation procedures.

This problem is addressed by current innovation dynamics in construction aimed at minimizing the large degree of knowledge waste and efficiency loss. Though varying in quality and scope, the innovation dynamics have the important commonality of attempting to overcome manifested structures and routines that have been established as a result of the project-based localized logic. They bring about new ideas, products or organizational settings as they are able to cross project boundaries. Main catalysts 
are the improvement of technical capabilities by developing highly sophisticated tools and machinery flexible enough to be used in different places, prefabrication of buildings and the establishment of an organizational service-oriented set-up beginning before and reaching beyond the physical project phase in order to facilitate communication among actors.

A second important characteristic of these innovations is their foundation on knowledge combinations with sources from different sectoral and organizational domains (STRAMBACH 2008; CREVOISIER/JEANNERAT 2009). Concerning the improvement of technical capabilities, the major knowledge flows come from machine construction, i.e. a peripheral part of the sector's value chain where working routines differ considerably and have more similarity with engineering than with construction. The idea of prefabricated construction heavily relies on the structures of other producing industries, especially the automotive industry, as houses are built within a permanent production facility. As regards new organizational (service) routines, influences are coming from new management approaches and include a general orientation towards a servicebased economy and the ICT sector.

The current situation in construction provides fruitful ground for studying the major research topic of this special issue, namely the relation between path dependency, path plasticity, and knowledge combinations. While some of the other contributions have an explicit spatial orientation, this paper studies path plasticity primarily from a sectoral perspective, though the matter of locality will be emphasized. In line with STRAMBACH (2010), path plasticity is understood as the range of possibilities through which change is shaped within an industry's dominant development path without resulting in its total transformation. Thereby, the notion of path plasticity takes the critique of a too strict and polarized view of path development being either considered as incremental or radical as a starting point. Incremental change is seen as a mechanism supporting continuous path development and institutional stability through positive feedback mechanisms and increasing returns (PIERSON 2000). Institutional adaptation happens without troublesome periods of mismatch between the market and its corresponding institutional framework (Dosi 1988). On the other hand, radical or disruptive change is seen as leading to the total transformation of an innovation system's development path, since the mismatch between market trends and institutional frameworks is irreconcilable. This polarity neglects the many facets of change happening between structural/ institutional stability and radical system disruptions (Streeck/Thelen 2005; Dolata 2007; StRAmbach 2010), which in this special issue will be studied under the aspect of path plasticity.

In the following, path plasticity is explored through the balance of change and continuity within innovation dynamics in construction. The balance of change and continuity is considered as the specific sectoral scope for path plasticity providing the corridor in which change happens without causing radical change. It needs to be negotiated among actors and institutional frameworks. In the case of construction, this will especially concern the labour market, the inter-firm division of work and related governance structures. Depending on the innovation, the degree of change required for its implementation differs and hence related path plasticity and the impact on the direction of sectoral change as a whole.

The paper begins with discussing the context of knowledge production in the construction sector both with regard to internationally effective and specific German attributes. As shown below, it is fundamentally configured by the projectbased nature and resulting spatial fragmentation. Then the current innovation dynamics aimed at changing manifested project-based working routines and overcoming localized structures are analyzed. They are discussed from an analytical point of view and exemplified by a number of concrete innovation cases that have been intensively studied within the frame of national research projects on the sector's innovation dynamics. The cases are assessed according to their degree of change and potential impact on the direction of sectoral development. The paper concludes with a discussion of the balance of change and continuity in the development path of construction and its implications for understanding path plasticity and knowledge combinations in economic change.

\section{The context of knowledge production in the construction sector}

The construction industry is a project-based industry par excellence (GRABHER 2002; DUBOIS/ GADDE 2002) and the generation of practical knowledge for planning and executing projects 
is both positively and negatively influenced by the project nature through which each project can develop unique characteristics (STYHRE 2008). Uniqueness originates in the place-specifics of the site, different building owners, the environment or the legal frame and requires tailormade solutions since one-size-fits-all attempts are likely to be inappropriate. Often, solutions are developed as a reaction to problems arising during the construction process (SENARATNE/ SEXTON 2011) that need to be solved quickly and efficiently with the competences at hand. They have a considerable tacit dimension and are derived from the experiences of different trades.

\section{The German construction sector - main characteristics}

In 2010, around 2.4 mio. people with social insurance were employed in the German construction industry ( $11 \%$ of all employees with social insurance in Germany). With the exception of the two companies Bilfinger Berger and Hochtief which belong to the ten largest construction companies in the world, the German construction industry consists of small and medium sized enterprises (SME). On average, German construction companies have ten employees (which is above the European average of approx. six employees).

The small-scale company structure goes hand in hand with a spatially dispersed distribution of the value-added chain. This results in a low level of competitiveness at international, and even interregional, level. Even though European efforts concerning common standard setting are continuously implemented, there is still a strongly national-oriented development path. Technical and labour market regulation, trades being limited to specific functions and sectoral governance structures characterized through inter-firm division of labour, concretize the specifics of the path (NORDHAUSE-JANZ et al. 2011).

As a general characteristic of project-based industries, there is a high risk reinventing the wheel in many projects, or put differently, there is the possibility of high knowledge waste (SYDOw et al. 2004) since knowledge transfer across projects appears to be a challenging task. Rose/ MANLEY (2012) consider innovation adoption in construction as being particularly hampered by the sector's complex innovation system that has an innovation gap (TAYLOR/LEVITT 2005) between the project and the cross-project mesolevel thus hindering innovations and knowledge which are to be scaled-up. Therefore, in an approach to minimize knowledge loss, ENGWALL (2003) makes a plea for construction projects not to be viewed as isolated islands but for conceptual and practical discussion on transfer channels, communication and storage mechanisms to anchor the single project in its wider context (cp. also CARRILLO et al. 2011). The innovation strategies analysed below should be viewed in this light.

Further distinctive characteristics of the sector provoked by the project-based nature are a high degree of complexity, local boundedness, loose coupling, and a strong institutionalization. These characteristics constitute the context of know- ledge production in construction and are essential for understanding the sector's structural deficits which constitute the innovation gap.

\section{Complexity}

Construction projects are among the most complex production activities in the economy. They require intensive knowledge exchange and wellestablished communication channels among the actors involved. GIDADO (1996) notions two basic features of the complexity, namely uncertainty and interdependency. Uncertainty arises due to the one-off nature of construction projects (see also Dubois/Gadde 2002, 622): The local environment is unfamiliar to management, i.e. the site may, at some stage, disclose unforeseen challenges, new and unknown actors may appear, material delivery and workflow might not match sufficiently, building owners might change their minds about design features, and importantly, weather is unpredictable and can cause major process delays. The high level of uncertainty leads, according to JENNINGS (2012), to a systematic underestimation of costs in largescale budgeting processes and even more so in mega projects. His very recent example is the budgeting of the London 2012 Olympic Games 
where costs exceptionally overran. Interdependency relates to sequencing various operations to form a workflow. The major challenge lies in coordinating activities and maintaining an appropriate time-space synchronization of the different trades to ensure a maximum level of efficiency (put simply, a painter cannot start painting a wall before is has been finished). Construction projects commence with comprehensive planning which combines knowledge related to engineering, law and regulations, architecture, planning, design, and project management. With the physical beginning, manifold processes happen simultaneously constituting an interdependent network with complex interfaces (GANN/ SALTER 2000). Knowledge and competences of different trades, high or low tech, manufactured or standardized, are combined and adapted to the building's uniqueness and local specifics.

\section{Locally bounded}

In contrast to industrial value chains where products are manufactured at permanent locations, the construction sector usually produces within "moving factories" in which products are visibly or invisibly adapted to local specifics. Even with increasing standardization and industrialization, the physical environment of every project requires new knowledge combinations of routinized and tailored solutions (Dubois/GAdDE 2002). Local dependence limits the potential for economies of scale leading to a comparatively low level of national or international expansion. As a consequence, most German construction companies are medium sized and operate on a regional basis (BOSCH/ZÜHLKERobinet 1999; NordhaUSE-JANZ et al. 2011). Another disadvantage of local boundedness is a spatially dispersed sectoral structure, since a process of industrial and spatial concentration, as for example in automotive or engineering industries, has not taken place. This has direct implications for knowledge creation, flows and diffusion. Similar stocks of knowledge are rather equally distributed across space. Every construction project can be considered as a knowledge creating entity constituted by regionally-based actors. However, they still need to start from scratch and the call for many repetitive components remains (cp. the renewal paradox). Against this background, the development of highly specialized knowledge seems to be economically inappropriate, since it cannot be applied in daily projects operations. This has resulted in a certain dualism of roles between the core parts of the construction sector where knowledge generation is practice-based, highly tacit and takes place incrementally by developing non-technological process and organizational innovations. In turn, high-technology specialization is found in the more peripheral parts of the value chain, especially in areas such as machinery equipment and new materials research.

\section{Loose coupling}

Loose coupling in contrast to stable relations of actors is a direct implication of the projectbased structure. Its advantage is its flexibility in arranging a constellation of trades and competences tailored to local conditions, rather than being bound to certain actors through formal contractual or informal dependencies (DuBoIS/ GADDE 2002). LARSEN (2011) considers loosely coupled actors and strong complementarity of knowledge bases a disadvantage in terms of developing working routines throughout the lifetime of a construction project. The different trade backgrounds alongside an exceptionally narrow time frame are a barrier for actors in overcoming their cognitive distance and constituting a trustful and synergetic community of practice. As an alternative when describing the characteristics of project-based industries, SYDOw et al. (2004) and LiNDKVIST (2005) suggest the notion collectivity of practice. Collectivities of practice build to a lesser extent on a tightly knit group and the solid ground of a common knowledge base. They take advantage of loose coupling by linking diverse knowledge bases thereby enabling the combination of different knowledge domains. Such collectives depend on well-connected and informed individuals acting as facilitators and mediators in the process of knowledge integration. Of the broader consequences of the sector's loosely coupled structures is a segmented value chain with each part having separated regulations, logics and routines being even more intensified by the largely disconnected tasks of planning, design and physical construction (MANLEY/MCFALLAN 2006; ButZin/REHFELD 2009). Recently the latter aspect is increasingly being seen as needing to be approached from an integrated perspective combining planners, architects and practitioners in order to optimize efficiency.

\section{Strong institutionalization}

Formal and informal institutionalization in construction is strong (KADEFORS 1995) and 
its main function is to mediate stability. To a great extent, this is attributed to the complexity and uncertainty of construction projects, the long durability of buildings and the comparatively short construction phase, different trades working together and the large amounts of money spent on construction projects. In this high risk environment, institutions, understood as formal and informal routines, rules, norms and regulations (cp. EDQUIST/JOHNSON 1997), are first and foremost considered as providing stability and only subsequently the soft features of giving orientation, guidelines and reliability.

KADEFORS (1995, 401) distinguishes different institutional settings as rule-guiding in construction: Legislative regulations affect planning (zoning maps), buildings and building practices in terms of formal liabilities for the work done. Standardization is highly advanced in many aspects reaching from specified material properties to standardized contracts and from the design of work processes to protective clothing. In the tendering system the building owner defines tasks to be undertaken and the related standards to be applied during a project and firms then bid on the job. Decisions are mostly taken on a least-cost basis and there is almost no room for firms to respond by offering work with a more radical innovation or procedure. Though less explicit, different roles in construction projects seem to be pre-defined and bring with them strong cultural norms and value-orientations (see also Pemsel/Widén 2011). Learning and routine arise through the uniformity of roles and play a large part in contributing to the value chain's segmentation.

In the following text we will analyse the innovation strategies of construction firms that tackle efficiency and competence losses related to the project-based structure. The innovation strategies especially concern the challenge of developing technical equipment and organizational routines flexible enough to be applied across different construction projects in order to overcome the locality problem and the innovation gap caused by the distinctive sectoral characteristics as described above. The major analytical focus is to assess the degree of change required for their implementation - i.e. the question in how far they change labour market structures, the inter-firm division of work or related governance structures.

\section{Changing project-based structures: strategies, knowledge combinations and innovations}

Construction is a very complex, locally bound process. Complexity calls for intense cooperation and communication - costs resulting from insufficient communication and misunderstandings between stakeholders are significantly high. The matter of locality is a major causation; there is widespread belief that the uniqueness and related problems of each construction project hinder standardized solutions.

Against this background, the three innovation strategies examined below may be considered as attempts to change the path-dependent production logic by overcoming attributes related to the project-based nature. The first focuses on minimizing the specific problems resulting from local circumstances by enhancing technical capabilities. The obvious way is to develop durable tools or machinery equipment that can be used in different places. The second is an orientation towards the industrialization models of other industries such as the automotive industry and mainly concerns the prefabrication of buildings within permanent production halls. The third aims at expanding competences thereby overcoming communication problems resulting from complexity, the loosely coupled interrelations and the unique character of building projects. New organizational and service models, as well as intensified applications of ICT based management systems, are the prevailing approaches. The three strategies will be discussed and underpinned by concrete innovation developments reflecting current activities. The innovation developments are then analysed according to their degree of change and the resulting impact on the direction of sectoral change as a whole. Results are based upon research of two projects on innovation processes and strategies in construction. ${ }^{1}$ The fieldwork to study the innovation processes was mainly undertaken using a qualitative research methodology called innovation biographies (cp. ButZIN et al. 2012). The methodology is designed to obtain detailed insights of knowledge flows and dynamics of innovations. It applies a mixed-method approach which incorporates varying interview techniques and qualitative egocentric network analysis. The methodology enables reconstruction of the development process of an innovation from the initial idea through to its implementation as a service, product or organizational innovation. 


\section{Innovation strategy I: Enhancing technical capabilities}

Each construction project is unique and requires tailored technical solutions. Especially in larger construction projects, technical equipment and tools are developed to be applied in only one project. Alternatively, modularized, step-wise, technical procedures can be adapted and modified according to local specifics. However, both attempts have components of inefficiency; the new development of technical equipment (an example could be a temporary bridge in road construction) for each construction project is repetitive and time-consuming. The alternative suggestion could be subject to improvements by finding ways to combine two working steps. An example would be the new drilling process outlined below that combines the two steps of drilling and tunneling.

From a knowledge combination perspective, the strategy of enhancing technical capabilities in order to set them apart from the project logic is of considerable interest, for several reasons. Firstly, the main actors setting out impulses come from the value chain's synthetic knowledge-based (AsHeIM/COENEN 2005), peripheral parts of machine building, material development or tool making. These are parts where sectoral borders intersect with engineering and where the knowledge generation processes and working routines are thus influenced by cross-sectoral knowledge combinations. This results, secondly, in routines being disentangled from the project structure of the construction sector's core parts. Actors are based in permanent locations and carry out continuous research and development activities that build upon each other. Therefore, it seems only logical that technical innovations developed in these parts of the value chain are designed for multiple usages in different places since developers are not confronted with the restrictions of projects on a daily basis. As a consequence, thirdly, the implementation of technical innovation in construction projects is an encounter of the two production logics "temporal project" vs. "continuous development" and their different knowledge domains "practice-based manufacturing/tacit" vs. "scientific/engineering". In what follows, two characteristic technical innovations are discussed to examine their potential for change in future path development.

A novel drilling process: The drilling process unites the two working steps of horizontal drill- ing and micro-tunnelling and was developed by a world-leading firm for tunnelling technologies. An example of its application is the installation of a sewage pipe crossing under a river where the driller simultaneously installs the pipe while drilling the hole. The significant time saving achieved by simultaneous tunnel drilling and pipe insertion is a considerable efficiency saving innovation. Most challenging was the construction of the drilling machine in a way that allowed its application in all possible locations (e. g. different soil properties, horizontal and vertical curves). The pilot project was carried out in a southern German municipality where a new sewage system was installed across the Rhine river. Prerequisite to its implementation were changes in the municipality's tendering system.

Degree of change and potential impact on the direction of path development: The novel drilling process has won several awards due to its highly sophisticated technical applications and is among the firm's flagship products. Nevertheless, though clearly overcoming one-off applications, its potential for changing path development is limited since the innovation contributes to the further specialization of the company, does not diffuse and does not impact on working routines on a broader level. It follows a given path instead of initiating broader-level change.

A re-usable temporary bridge: Temporary bridges are required in railway services if construction work needs to be done to a permanent rail bridge. The usual routine would be to statically calculate and design the temporary bridge and then build it for the sole purpose of an ersatz building to be deconstructed as soon as the construction work is finished. Though this is an extraordinary cost-intensive procedure, it is repeated in every new project in order to meet local conditions (e.g. through varying lengths of bridges) and regulative aspects: Each time it is required to have type testing and to document the quality of the deployed steel. This is undertaken by an officially approved testing authority. The quality management team of a leading bridge building firm suggested developing a new bridge that could be re-used in different projects thereby saving time and money. Similar to the drilling process, the major challenge was to include all possible project conditions, e.g. calculating from low to extreme weights of trains and considering different topographies (this is an illustrative example of how locality can limit 
the scope innovation or respectively call for extra creativity). Another challenge was that official regulations had not foreseen the need for permanent permissions for the temporary installation of ersatz buildings. Instead it was necessary to obtain permission for each new project. This included an intensive testing of whether the bridge was adequately constructed according to local conditions. In cooperation with the Federal Railway Authority a solution was found that included some re-labelling to finally certify permission as for a permanent installation.

Degree of change and potential impact on the direction of path development: Similar to the drilling process, the re-usable temporary bridge is more important in terms of company development than of path development. New technical knowledge was created in order to configure the technical requirements and has basically contributed to path continuation rather than to notable change, at least from a technical perspective. What distinguishes the bridge from the drilling procedure is its relatedness with the respective formal institutional setting and the consequence of changing parts of the existing regulatory framework that formerly followed a one-off logic.

\section{Innovation strategy II: prefabrication}

The more ambitious way to overcome locality is industrialization. Prefabrication of single components is the starting point; industrial production of complex sub-systems (walls with all infrastructures, such as heating systems) is the sophisticated further development. Both are produced at a fixed location in permanent rather than in "moving factories". Numbers are growing in the case of car parks and office buildings, whereas it remains a niche segment in the area of school buildings and housing. The principle is to take advantage of integrating as many working steps as possible under one roof by e. g. having full control over the workflow in terms of time-settings, material delivery, the building-up of routines through standardized production procedures and the integration of trades (now being all employees of the same company). Major influences come from sectors with industrialized production structures, especially the automotive industry, where permanent production facilities are an established component of the sectoral structure. There are two areas of knowledge combinations. Firstly, automotive production structures and knowledge concerning industrial- ization is combined with the requirements of the construction sector. Secondly, different trades are employed by one company including better opportunities of knowledge exchange. However, the market of prefabricated components and buildings is a complex one. In housing especially, implementation is confronted with the problem of consumer reservations against the uniform design of houses. A recent example of market failure was IKEA's prefabricated BoKlok house which only managed a few sales on the German market. The project attracted little interest and consequently it was cancelled in Germany (Bien-Zenker AG 2011).

The case of school buildings: The developing company was already considerably successful in the industrial production of commercial buildings and multi-story car parks with low-individuality building design. Schools seemed to be another type of building equally fitting into this logic and development began with a first construction project. During preparation, the building owners had been hesitant to assign the company, because of established scepticism towards prefabricated houses. Other problems concerned the prefabrication of higher stability and safety components thereby partly counteracting the advantages of the systemic construction system. These problems required external expert certification. Furthermore, the on-site assembling of components was done by an external company inexperienced in assembling prefabricated components. Therefore, considerable efforts needed to be put into training the external company's employees since the so-called 'systemic buildings' have higher workflow and construction requirements resulting in changing working routines.

Degree of change and potential impact on the direction of path development: We consider industrialized construction of buildings such as schools as highly influential in terms of overcoming the localized project structure. It combines different actors' (trades) embedded knowledge in one place that not only provides the opportunity to develop from a collectivity of practice into a community of practice, but also installs continuation for the improvement of routines and workflow procedures. However, how far a completely prefabricated house becomes a successful product or whether prefabrication reaches a certain limit and is only of relevance for commercial buildings and building components, remains an open issue. 


\section{Innovation Strategy III: Expansion of competences - overcoming communication problems}

The third innovation strategy aims at expanding competences in order to overcome communication problems by intensifying service orientation and a stronger use of ICT based management systems. Service orientation brings a shift from competition based on cost efficiency towards one based on the added value of a product. It represents a transition from old modes of construction work towards new ones by focusing on services rather than on products (OLIVA/KALLENBERG 2003; GEBAUER et al. 2008). Instead of targeting mere product delivery, construction firms increasingly put efforts into bundling design, construction and maintenance/facility management (LEIRINGER/BRÖCHNER 2010). They concentrate on the entire life cycle of a product with the broader aim of prolonging the firm's specific value-added chain by particular service components (HoLm 2000). Building upon the firm knowledge related to technical and engineering functions, it also implies an expansion of competences related to performance, quality management and customer relations (LEIRINGER/ BRÖCHNER 2010). The latter two are of particular importance, as in a service-based approach, the firm and the clients usually collaborate on a long-term basis which reaches far beyond the period of the actual construction process.

Indeed, such a change in a sector's competition and working routines cannot happen without the generation and application of new knowledge domains through which service orientation is implemented and carried out. Dominant engineering and practice-based routines defined through materials, machinery and technical features are complemented by customer relation management, service design, financial engineering or marketing components and go hand in hand with the creation of completely new job descriptions. Furthermore, service orientation also affects the institutional arrangement. Not only is there an existing need for new contractual standards and finance models or for a new interpretation of roles from product deliverer to service provider, it also has major implications for working routines and the project structure of the sector as a whole. Though service-led buildings possess one-off characteristics and still can be considered as project-based, the life cycle perspective prolongs the time frame and thereby provides ground for the accumulation of know- ledge including better opportunities for learning, feedback and process improvement.

A service oriented business model: In parallel to the above mentioned industrialized construction of schools, the developing firm has undergone a significant change towards a new business model with an integrative perspective on its activities. Concretely, this implied developing services and functions enabling the design, construction and maintenance of buildings instead of only fulfilling the core part of physical construction. The competence portfolio of the company was considerably enlarged, uniting all necessary competences for leading building projects from the beginning and throughout the entire life cycle. Importantly, this results in efficiency gains since knowledge obtained during construction can be used for maintenance, or vice versa, knowledge of maintenance requirements can be included in the construction phase.

Degree of change and potential impact on the direction of path development: Impacts in terms of path change are medium to high, it changes actor constellations whereby construction firms now take over design and facility management. There are changes in power relations between clients and contractors evolving from their long-term, mutual relationship.

Building teams: The organizational form of building teams originates from the Netherlands (bouwteam) where it is a successful alternative to the general contractor model in which there are strictly separated roles between planning, construction and the building owner. It is designed for housing projects. Building teams have a flat hierarchy and integrate all relevant professions as well as the building owner already from the start. It begins with the common planning of workflow and intensive knowledge exchange of experiences across trades. Architects have a special role in building teams as they need to be a communication interface and coordinate the workflow. Working successfully in a building team requires a new understanding of traditional roles. Trade firms need to perform planning instead of mere construction; architects need to accept trade firms as equal partners.

Degree of change and potential impact on the direction of path development: Although construction projects with building teams have been carried out for almost twenty years, particularly in southern Germany, concept diffusion has hap- 
pened very slowly. Despite comprehensive information, for example a manual of how to work in building teams published by the Chamber of Architects in Baden-Württemberg (Architektenkammer Baden-Württemberg 2009), there are only selective building team projects. During the building process a lot of combinatorial knowledge exchange takes place in building teams. But as long as the concept is not adopted by others, its potential for sectoral change remains on a medium level.

Another component of the strategy to expand competences thereby overcoming the communication problems is intensive usage of ICT based management systems to simplify information flow. However, as yet, highly sophisticated IT systems seem not to be as promising as had been expected. One reason might be that IT systems and building projects are equally complex, as the following two cases show.

The limits of ICT-renovation of a historic building, and building information modelling at the Elbphilharmonie: The renovation of a historic building illustrates the change of routines in project organization due to enormous time pressure. Deadline for renovation was the beginning of the European Capital of Culture 2010 in the Ruhr area, Germany. Construction could not be started well in advance since the final approval for EU cofinance was outstanding. Many different working steps were conducted in parallel. Although the design phase was not finished, work independent of design and other planning was started and tenders for the interior were already published. Due to the situation, the contractor decided to downscale the use of electronically-based project management systems to a minimum as training all the users would have been enormously timeconsuming. Normally, in large projects like this formalized communication channels and detailed information documentation are essential components for a smooth project flow. In this case, regular verbal meetings took place within a circle of those with top responsibility in order to balance out the lack of electronically available information. Paper documentation too, was minimized to save time although this ran the risk of considerable knowledge loss should central people have changed their jobs or moved on.

Another case is the application of a 3D building information model in the (on-going) construction process of the new concert hall Elbphilharmonie in Hamburg. 3D building information models are developed in order to visualize a building to be constructed. They facilitate the planning phase in terms of simplifying decision-making and calculating expected costs. Every new development, e.g. a change in the floor plan, is fed into the modelling system which than calculates the resulting consequences such as new volumes of steel for the other trades. Moreover, it is also the basis for decisions taken during the life cycle of a building up until its demolition. Right from the beginning, the planning and construction process of the Elbphilharmonie was based upon a building information model and the actual costs should have been known (theoretically). Nevertheless, the project was stopped half-way since costs for constructing the roof exploded during the processes. There is currently a serious dispute between Hamburg and the contractor Hochtief about who should pay.

Degree of change and potential impact on the direction of path development: It is questionable whether new competences in applying sophisticated IT solutions facilitate the overcoming of communication barriers in construction. IT solutions seem to be unable to compensate the tension between the need to explicate knowledge in order to provide information for the IT system and the tacit dimension of experience-based knowledge crucial in the everyday routines on construction sites. Though being hyped as a promising approach the improvement of communication does not depend on ICT. One hypothesis is that strengthening communication is more a social than a technical problem.

\section{Discussion and conclusion}

The innovation trends which influence localized product-based production structures as discussed in this paper, underpin the potential of combining knowledge from different sectors and from along the value chain. However, since not every approach is equally effective in generating impact at the broader level, it is also important to discuss why some of the presented innovations seem to be less successful than others. This is especially important against the background of finding a balanced mixture of sectoral change and continuity describing the scope for path plasticity - i.e. the corridor in which change happens without causing radical transformation.

When looking closer at the innovation trends and cases, there are some observable patterns. 
Though clearly overcoming the construction sector's locality problem through process automation, the improvement of technical capabilities seems well-matched to the given sectoral path and optimizes it within a known development route. There is only a minor degree of negotiating with other actors or the formal institutional framework. Solutions to deal with barriers (long-term certification, finding a pilot project) that arise and which are part of any innovation process, are found within a reasonable time frame and without major changes of the technical components.

The picture is completely different in the case of prefabricated buildings. By adopting the industrialization logic of other producing industries, prefabrication highly affects the sector's working routines significantly through combining and integrating the knowledge of different trades, changing the established division of labour, allowing continuous long-term development processes and through the physical re-location of a construction project into permanent production halls. The implementation of prefabricated buildings results in a high degree of path plasticity, though being only applicable in certain segments of the sector (e.g. car parks, private housing, schools and office buildings).

The same is true for emerging service orientation. Contrary to prefabrication which changes existing structures, service orientation is connected to the setting-up of a completely new domain within the construction sector and is accompanied by the co-evolution of necessary structures through which it is implemented, e.g. public-private partnership models (PPP), new job descriptions, a growing importance of facility management. This new sub-sectoral domain is still an area of experimentation resulting in various models being tested out (building teams, life cycle orientation, PPP). With respect to ICT tools, it is noticeable that they partially face high bottlenecks during implementation and seem to have limited potential in provoking change in the sector's development path due to some resistance against them. The current requirements to gainfully use building information models or ICT-based project management tools seem to be too high and to date they have not helped to reduce complexity and communication problems. An underestimated explanation is that in order to fully plan a construction process with ICT, large amounts of tacit knowledge need to explicated and fed into the software. This kind of bridging or combinatorial capability between tacit construction knowledge embedded within the trades and formalized, electronically-based planning and communication tools needs further improvement. In Tab. 1 the key determinants of each innovation process in terms of knowledge sharing and combinations, resulting bottlenecks and the potential impact on sectoral change are summarized.

Furthermore, some considerations should be made concerning the role of the institutional framework. Overcoming project structures seems to concern formal and informal institutions equally. With respect to the regulative framework constituting the context of working routines, flexibility to implement innovations is established through finding creative solutions within existing regulations rather than through the establishment of new ones. Examples are the renaming of the temporary bridge that allowed permanent type approval, differently interpreted tendering procedures, or expert certifications balancing out a lack of institutional standardization. In other words, there seems to be scope for the flexible interpretation of the formalized institutional framework (STRAMBACH 2010).

However, the potential for significant sectoral change rests with the development of new working and organizational routines connected to the more informally constituted institutions (EDQUIST/JOHNSON 1997). Taken together, they are much more promising in terms of uncoupling from the project-based structures and the related problem of local boundedness. They not only imply the cooperative set-up of teams constituted by clients, project managers and trades but also result in new building teams, prefabrication of buildings, and a life cycle orientation. Furthermore, they allow the tapping into various knowledge sources of the entire construction's value chain and of other sectors.

\section{Note}

1 The findings are based on two research projects on innovation processes and strategies in construction, which were funded by the Federal Office for Building and Regional Planning (Butzin/Rehfeld 2009; NordhauseJANZ et al. 2011), called "Innovation biographies in the German construction sector" (Contract number Z 6 - 10.08.18.7-07.01) and "Innovation strategies in construction. An international comparison" (Contract number $\mathrm{SF}-10.08 \cdot 17.7 .-09.30)$. 
Tab.1: Overview of innovations and impact on sectoral change

\begin{tabular}{|c|c|c|c|c|c|}
\hline & $\begin{array}{l}\text { Type of } \\
\text { innovation }\end{array}$ & $\begin{array}{l}\text { Mode of knowledge } \\
\text { sharing and know- } \\
\text { ledge combinations }\end{array}$ & Bottlenecks & $\begin{array}{l}\text { Impact on } \\
\text { sectoral change/ } \\
\text { path plasticity }\end{array}$ & $\begin{array}{l}\text { Path changing } \\
\text { idea behind }\end{array}$ \\
\hline $\begin{array}{l}\text { Drilling } \\
\text { process }\end{array}$ & $\begin{array}{l}\text { Process } \\
\text { innovation } \\
\text { (technical). }\end{array}$ & $\begin{array}{l}\text { Starts out analyti- } \\
\text { cally-based with } \\
\text { need for contextuali- } \\
\text { zation during pilot }\end{array}$ & $\begin{array}{l}\text { Medium } \\
\text { (difficulties in } \\
\text { finding a pilot } \\
\text { project). }\end{array}$ & $\begin{array}{l}\text { Limited, } \\
\text { optimization of the } \\
\text { given path, mostly } \\
\text { change of internal } \\
\text { routines }\end{array}$ & $\begin{array}{l}\text { Process } \\
\text { automation }\end{array}$ \\
\hline $\begin{array}{l}\text { Temporary } \\
\text { bridge }\end{array}$ & $\begin{array}{l}\text { Process } \\
\text { innovation } \\
\text { (technical) }\end{array}$ & $\begin{array}{l}\text { De- and re- } \\
\text { contextualization } \\
\text { (from a one-off tool } \\
\text { to reusable) }\end{array}$ & $\begin{array}{l}\text { Medium } \\
\text { (certification) }\end{array}$ & $\begin{array}{l}\text { Limited, } \\
\text { optimization of the } \\
\text { given path, mostly } \\
\text { change of internal } \\
\text { routines }\end{array}$ & $\begin{array}{l}\text { Process } \\
\text { automation }\end{array}$ \\
\hline $\begin{array}{l}\text { Prefabricated } \\
\text { buildings }\end{array}$ & $\begin{array}{l}\text { System } \\
\text { innovation } \\
\text { (technical) }\end{array}$ & $\begin{array}{l}\text { Knowledge integra- } \\
\text { tion (knowledge of } \\
\text { all trades is com- } \\
\text { bined and integrated, } \\
\text { producing indust- } \\
\text { ries) }\end{array}$ & $\begin{array}{l}\text { High, } \\
\text { because } \\
\text { affecting divi- } \\
\text { sion of labour }\end{array}$ & $\begin{array}{l}\text { High, } \\
\text { because it affects the } \\
\text { division of work bet- } \\
\text { ween trades, requires } \\
\text { new working proce- } \\
\text { dures and overcomes } \\
\text { the locality problem }\end{array}$ & Industrialization \\
\hline $\begin{array}{l}\text { Service busi- } \\
\text { ness model }\end{array}$ & $\begin{array}{l}\text { Product } \\
\text { resp. Service } \\
\text { innovation }\end{array}$ & $\begin{array}{l}\text { Cross-sector know- } \\
\text { ledge combination } \\
\text { (construction, ser- } \\
\text { vice) }\end{array}$ & $\begin{array}{l}\text { Medium to } \\
\text { high, because } \\
\text { new market }\end{array}$ & $\begin{array}{l}\text { High, } \\
\text { new actor constella- } \\
\text { tions, reconfiguration } \\
\text { of value chain }\end{array}$ & $\begin{array}{l}\text { System } \\
\text { integration }\end{array}$ \\
\hline $\begin{array}{l}\text { Building } \\
\text { teams }\end{array}$ & $\begin{array}{l}\text { Process inno- } \\
\text { vation (com- } \\
\text { munication } \\
\text { and planning) }\end{array}$ & $\begin{array}{l}\text { Knowledge integra- } \\
\text { tion (core part of } \\
\text { sector and customer) }\end{array}$ & $\begin{array}{l}\text { Medium, } \\
\text { depending on } \\
\text { trust }\end{array}$ & $\begin{array}{l}\text { Medium, } \\
\text { new division of labour } \\
\text { on inter-firm level but } \\
\text { slow diffusion }\end{array}$ & $\begin{array}{l}\text { Network } \\
\text { company }\end{array}$ \\
\hline ICT tools & $\begin{array}{l}\text { Process inno- } \\
\text { vation (com- } \\
\text { munication } \\
\text { and planning) }\end{array}$ & $\begin{array}{l}\text { Knowledge needs } \\
\text { to be explicated and } \\
\text { newly combined to } \\
\text { merge different } \\
\text { sector logics } \\
\text { (ICT/construction) }\end{array}$ & $\begin{array}{l}\text { High, } \\
\text { because con- } \\
\text { flict with tacit } \\
\text { knowledge }\end{array}$ & $\begin{array}{l}\text { Limited, } \\
\text { because of strong } \\
\text { routines of tacit } \\
\text { knowledge hindering } \\
\text { broader level change }\end{array}$ & $\begin{array}{l}\text { Flexible } \\
\text { standardization }\end{array}$ \\
\hline
\end{tabular}

Source: own compilation

\section{References}

Architektenkammer Baden-Württemberg (Ed.) (2009): Bauteam - Ein Leitfaden für Architekten und Handwerker. Internet: http://www.akbw.de/fileadmin/download/dokumenten datenbank/AKBW Broschueren/Bauherreninformationen/Bauteam-Leitfaden_ergaenzt.pdf, 24.9.2012.

Asheim, B. / CoEnen F. (2005): Knowledge bases and regional innovation systems. Comparing Nordic clusters. In: Research Policy, 34, 1173-1190.

Bien-Zenker $A G$ (2011): Geschäftsbericht 2011. Internet: http://www.bien-zenker.de/uploads/media/BIEN-ZENKER GB_2011.pdf, 24.9.2012.

Bosch, G. / ZüHLke-Robinet, K. (1999): Der Bauarbeitsmarkt in Deutschland. Zum Zusammenhang von Produktionsstrukturen, Arbeitsmarkt und Regulierungssystem. In: Industrielle Beziehungen, (6)3, 239-266.
Butzin, A. / RehFeld, D. / Widmaier, B. (Eds.) (2012): Innovationsbiographien. Räumliche und sektorale Dynamik. Baden Baden.

Butzin, A. / Rehfeld, D. (2009): Innovationsbiographien in der Bauwirtschaft. Abschlussbericht. Stuttgart. (Forschungsinitiative Zukunft Bau, 2718).

Carrillo, P. / Harding, J. / Choudhary, A. (2011): Knowledge discovery from post-project reviews. In: Construction Management and Economics, (29)7, 713-723.

Crevoisier, O./Jeannerat, H. (2009): Territorial knowledge dynamics. From the proximity paradigm to multilocation milieus. In: European Planning Studies, (17)8, 1223-1241.

DolatA, U. (2008): Technologische Innovationen und sektoraler Wandel. Eingriffstiefe, Adaptionsfähigkeit, Transformationsmuster: Ein analytischer Ansatz. In: Zeitschrift für Soziologie, (37)1, 42-59. 
Dosi, G. (1988): Technical change and economic theory. London. (IFIAS research series, 6).

DuBois, A. / GADDE, L. E. (2002): The construction industry as loosely coupled system: implications for productivity and innovation. In: Construction Management and Economics, 20, 621-631.

EDQuist, C./ Johnson, B. (1997): Institutions and organizations in systems of innovation. In: Edquist, C. (Ed.): Systems of innovations. Technologies, institutions and organisations. London/Washington, 41-64.

Ekstedt, E. / Lundin, R. / Wirdenius, H. (1992): Conceptions and renewal in Swedish construction companies. In: European Management Journal, (10)2, 202-209.

ENGWALL, M. (2003): No project is an island. Linking projects to history and context. In: Research Policy, (32)5, 789-808.

GANN, D. M. / SAlter, A. J. (2000): Innovation in projectbased, service-enhanced firms: the construction of complex products and systems. In: Research Policy, (29)7-8, 955972.

Gebauer, H. / Bravo-Sanchez, C. / Fleisch, E. (2008): Service strategies in product manufacturing companies. In: Business Strategy Series, (9)1, 12-20.

GidAdO, K.I. (1996): Project complexity. The focal point of construction production planning. In: Construction Management and Economics, 14, 213-225.

GraBHER, G. (2002): Cool projects, boring institutions. Temporary collaboration in social context. In: Regional Studies, (36)3, 205-214.

GRABHER, G. (2004): Temporary architectures of learning. Knowledge governance in project ecologies. In: Organization Studies, (25)9, 1491-1514.

Holm, M. G. (2000): Service management in housing refurbishment: a theoretical approach. In: Construction Management and Economics, (18)5, 525-533.

JENNINGS, W. (2012): Why costs overrun. Risk, optimism and uncertainty in budgeting for the London 2012 Olympic Games. In: Construction Management and Economics, (30)6, 455-462.

KADEFORS, A. (1995): Institutions in building projects: implications for flexibility and change. In: Scandinavian Journal of Management, (11)4, 395-408.

LARSEN, G.D. (2011): Understanding the early stages of the innovation diffusion process: awareness, influence and communication networks. In: Construction Management and Economics, (29)10, 987-1002.

LEIRINGER, R. / BRÖCHNER, J. (2010): Editorial: service-led construction projects. In: Construction Management and Economics, (28)11, 1123-1129.
LINDKVIST, L. (2005): Knowledge communities and knowledge collectivities. A typology of knowledge work in groups. In: Journal of Management Studies, (42)6, 1189 1210.

Manley, K. / Mcfallan, S. (2006): Exploring the drivers of firm-level innovation in the construction industry. In: Construction Management and Economics, (24)9, 911-920.

Nordhause-Janz, J. / Rehfeld, D. / Welschhoff, J. (2011): Innovationsstrategien am Bau im internationalen Vergleich. Berlin. (BMVBS-Online-Publikation 07/11).

Oliva, R. / KALlENBERG, R. (2003): Managing the transition from products to services. In: International Journal of Service Industry Management, (14)2, 160-172.

Pemsel, S. / WidÉn, K. (2011): Bridging boundaries between organizations in construction. In: Construction Management and Economics, 29, 495-506.

Pierson, P. (2000): Increasing returns, path dependence, and the study of politics. In: American Political Science Review, (94)4, 251-267.

Rose, T. M. / MANLEy, K. (2012): Adoption of innovative products on Australian road infrastructure projects. In: Construction Management and Economics, (30)4, 277-298.

Senaratne, S./Sexton, M. (2011): Managing change in construction projects. A knowledge-based approach. Chichester. (Innovation in the built environment).

Strambach, S. (2010): Path dependency and path plasticity. The coevolution of institutions and innovation - the German customized business software industry. In: Boschma, R. / Martin, R. (Eds.): Handbook of Evolutionary Economic Geography. Cheltenham/Northampton, 406-431.

Strambach, S. (2008): Knowledge intensive business services as drivers of multi-level knowledge dynamics. In: International journal of services technology and management, (10)2-4, 152-174.

Streeck, W. / Thelen, K. (2005): Beyond continuity. Institutional change in advanced political economies. Oxford.

Styhre, A. (2008): The role of social capital in knowledge sharing. The case of a specialist rock construction company. In: Construction Management and Economics, 26, 941951.

Sydow, J. / LindKvist, L. / DeFillippi, R. (2004): Editorial. Project-based organizations, embeddedness and repositories of knowledge. In: Organization Studies, (25)9, 14751489.

TAYLOR, J.E./LEVITT, R.E. (2005): Inter-organizational knowledge flow and innovation diffusion in project-based industries. Proceedings of the 38th Hawaii International Conference on System Sciences. Honolulu, 1-10. 